\title{
Ectoparasite infestation of free scavenging chickens reared under traditional backyard production system in Wolayita Zone, southern Ethiopia
}

\author{
Tesfaheywet Zeryehun ${ }^{1^{*}}$ and Yonas Yohannes ${ }^{1}$ \\ ${ }^{1}$ College of Veterinary Medicine, Haramaya University, P.O.Box 138, Dire Dawa, Ethiopia

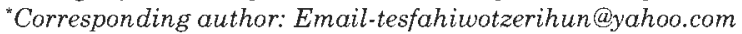

\begin{abstract}
This study was carried out to determine the prevalence and types of ectoparasite faunas and the associated host-related risk factors in free scavenging chickens in Wolayita Zone, Southern Ethiopia. Physical examination that involves hand picking and skin scrapping and laboratory investigation was employed in a total 450 chickens (198 male and 252 female).The present study revealed an overall prevalence of $40 \%(180 / 450)$. Three genera and seven species of ectoparasites were identified. Of the three genera, mites were the dominant ones $(24.9 \%)$ followed by lice $(13.8 \%)$ and ticks (1.3\%).Among the seven species of ectoparasites, Cnemidocoptes mutans $(61.1 \%)$ was the most prevalent species followed by Cuclotogaster heterographus (8.9\%) and Menopon gallinae(8.9\%); Goniocotes gallinae(8.3\%) and Menacanthus stramineus(8.3\%), while Argaspersicus 3.3\%(6/180) was the least identified. There was no significant difference $(p>0.05)$ in prevalence of ectoparasites with regard to sex, age and breeds of chickens except for Cnemidocoptes mutans which was more significantly $(p<0.05)$ prevalent in adults than growers and chicks, in local than exotic breeds, and in female than male chickens. This study revealed diverse fauna of ectoparasite in backyard chickens in the study area; hence integrated control strategies should be put in place to boost chicken productivity.
\end{abstract}

Keywords: Lice; Mites; Prevalence; ticks; Wolayta-zone.

http://dx.doi.org/10.4314/evj.v19i2.2

\section{Introduction}

The total poultry production of Ethiopia is estimated at 39.6 million (CSA, 2009 ) of which about $99 \%$ are raised under the traditional backyard system of management, while $1 \%$ are exotic breeds maintained under intensive management system Duguma (2009). Indigenous chickens reared under traditional scavenging system play significant role through their contribution to the cultural and social life of rural people (Gebre-Egziabher Mekonnen, 2007). Nonetheless, production of indigenous chicken in rural Ethiopia has been challenged with several constraints, among others, disease, predation, 
lack of feed, housing and poor management (Tadelle Dessie and Ogle B., 2001). Parasitism due to gastrointestinal helminthes and ectoparasite constitutes among the major causes that decrease productivity of chickens, but neglected as they are rarely lethal (Hagos Ashenafi and Eshetu Yimer, 2004; Hunduma Dinka et al., 2010).

The prevalence of most parasitic diseases in poultry seems to have been reduced in commercial poultry production, due to improvement in management (Tesfaheywet Zeryehun et al., 2012), although in rural scavenging poultry a number of parasites are widely distributed (Bagust, 1999; Hagos Ashenafi and Eshetu Yimer, 2004; Hunduma Dinka et al., 2010), strongly suggesting that traditional backyard poultry husbandry exposes chickens to many types of parasites.

Ectoparasites can affect the health of chickens by causing tissue damage and blood loss (Vegad, 2004), toxicosis (Aleya and Sabrina, 2011), dermatitis and allergies (Taylor et al., 2007). Furthermore, some ectoparasites act as vectors of a number of pathogens (Swai et al., 2010) and during periods of heavy infestation, may weaken them, and lower their resistance and may lead to death (Soulsby, 1982). Ectoparasites impose serious threat to the physiology and feed efficiency by giving continuous irritation and blood sucking effect thus they are associated with emaciation, anemia and eventually loss of production of egg and meat (Permin et al., 2002).

Although ectoparasites constitutes among the most prevalent and the major causes that decrease productivity of chickens in the traditional managed system, they are mostly neglected (Abebe Wossene et al., 1997; Hunduma Dinka et al., 2010). Moreover, there is paucity of information in the prevalence of ectoparasites of chickens in the different agricultural zones of Ethiopia, including the current study area. The aim of this study was to determine the prevalence of ectoparasites, identify the parasitic fauna and the host related risk factors in free scavenging chickens in the study area.

\section{Materials and Methods}

\section{Study area description}

The study was conducted in one of the 12 woredas of Wolayita Zone, namely Sodo Zuriya woreda in Southern nations and Nationalities Peoples' Regional State (SNNPRS) of Ethiopia, which is located $327 \mathrm{~km}$ away from Addis Ababa. In this study, five Peasant Associations (PAs) were included purposefully 
based on the availability of scavenging chickens in rural poultry population in the area. The selected woreda is located $6^{\circ} 50^{\prime} 97^{\prime \prime}$ North longitudinally and $37^{\circ} 4^{\prime} 412^{\prime \prime}$ East latitudes. The climatic structure of the woreda is manifested by long rainy seasons prevailing from June to September and short dry season occurring from January to March. The study area lies 1550-2950 meters above sea level (masl) and it receives an annual rainfall of $1200-1450 \mathrm{~mm}$. The total livestock population is: cattle 106,196 ; goat 4606 ; sheep 24,585 ; donkey 3872 ; mule 131; horse 121; poultry 14,982 (SZWRDO, 2012).

\section{Study population and sampling procedure}

The study was carried out from November 2013 to March 2014, on a total of 450 chickens managed under backyard production system by collecting data related with ectoparasitism in the study area. The sample size was determined based on the formula provided by Thrusfield (2005).

$$
\text { i.e. } \mathrm{N} \quad \begin{aligned}
=1.96^{2} & \frac{\mathrm{P}_{\frac{\mathrm{exp}}{}}^{\mathrm{d} 2}\left(1-\mathrm{P}_{\mathrm{exp}}\right)}{} \\
= & \underline{1.96^{2}} \frac{2 \times(1-0.5)}{0.5^{2}} \\
= & 384
\end{aligned}
$$

Where, $\mathrm{N}=$ sample size required

Pexp $=$ expected prevalence

$\mathrm{d}=$ desired absolute precision

In this formula expected prevalence of $50 \%$ and absolute precision of $95 \%$ were considered. Accordingly, a total 384 chickens were required for this study. However, the sample size was increased by a factor (0.17) to increase the precision of study thereby making the total number of chickens to be 450 . Hence, the 450 chickens were systematically selected from 5,500 chickens in the backyard production system of the selected PAs. Systematic sampling methods were applied after sampling interval was determined using the formula $\mathrm{K}=\mathrm{N} / \mathrm{n}$. Where: $\mathrm{N}=$ represents estimated total chickens for backyard farm in sampling frames; $n=$ represents allocated sample size and $K=$ interval of household to be sampled (Pfeiffer, 2002).Accordingly, at every 12 household intervals a chick was caught and examined.

Chickens of both sexes were included in the study and they were grouped into two groups as local and exotic (Rhodes Island Red) breeds. The chickens were 
classified as adults ( $>12$ months), growers (6-12 months) and chicks ( $<6$ months). The ages were determined subjectively based on the size of crown, length of spur and flexibility of the xiphoid cartilage according to Magwisha et al. (2002) together with information from the poultry farmers. The minimum sample size of the study was determined by the formula given by Thrusfield (2005).

\section{Protocol design and method}

The chickens were examined for the presence of ectoparasites and any visible lesions related to parasite infestation through palpation and inspection. The collected ectoparasites were preserved in labeled universal bottles containing $70-100 \%$ alcohol and they were transported to the WolayitaVeterinary Laboratory for identification using gross and microscopic identification keys given by Taylor et al .(2007).

\section{Statistical analysis}

The data collected was coded and fed into Microsoft-Excel spread sheet and analyzed by using SPSS version 20.0. Prevalence was determined by the formula described by Thrufield (2005) as the rate of number of infested animals and total number of animals in the population. Pearson's chi-square $\left(x^{2}\right)$ test was used to evaluate the associations of different explanatory variables (age, sex and breed) with prevalence of ectoparasite infestation. In all analysis, 95\% confidence intervals and $\mathrm{P}<0.05$ were set to indicate significance.

\section{Results}

\section{Overall prevalence of ectoparasites}

Out of the 450 chickens examined 180 chickens were infested with an overall prevalence of $40 \%$.

Two species of mites of the genus Acari, four species of lice of the genus Mallophaga, and one species of tick of the genus Argasidae were identified. Among the different types of ectoparasites examined, mites (26\%) were the dominant type of ectoparasite followed by lice and ticksand the difference was statistically significant $(p<0.05)$ (Table 1$)$. 
Table 1:Types of ectoparasites fauna in free ranging chickens.

\begin{tabular}{|c|c|c|c|c|c|}
\hline Ectoparasites & No. Examined & No. Infested & Prevalence (\%) & $95 \% \mathrm{CI}$ & O2 (p-value) \\
\hline Mites & 450 & 117 & $26.0 \%$ & $19.8-28.0$ & $8.499(0.004)$ \\
\hline Lice & 450 & 62 & $13.8 \%$ & $10.3-17.0$ & \\
\hline Ticks & 450 & 6 & $1.30 \%$ & $0.4-2.4$ & \\
\hline
\end{tabular}

In the present study seven species of ectoparasites were found distribute in almost all part of the body; however, they are more concentrated in the feather, leg and ventral part of the body and few are found on the neck and comb areas (Table 2).

Table 2: Species based prevalence of ectoparasites and their site of attachment.

\begin{tabular}{|c|c|c|c|c|}
\hline Species of Ectoparasites & $\begin{array}{l}\text { No. } \\
\text { Infested }\end{array}$ & $\begin{array}{l}\text { Prevalence } \\
(\%)\end{array}$ & $95 \%$ CI & $\begin{array}{l}\text { Site of } \\
\text { Attachment }\end{array}$ \\
\hline \multicolumn{5}{|l|}{ Mites } \\
\hline Cnemidocoptes mutans & 110 & 24.4 & $20.7-28.4$ & Lower limb (non-feather part) \\
\hline Cnemidocoptes gallinae & 7 & 1.6 & $0.4-2.7$ & Base of the feather \\
\hline \multicolumn{5}{|l|}{ Lice } \\
\hline Cuclotogaster heterographus & $\mathrm{s} 16$ & 3.6 & $2.0-5.3$ & Comb, head, neck \\
\hline Menopon gallinae & 16 & 3.6 & $2.0-5.3$ & Thigh, wing, leg \\
\hline Goniocotes gallinae & 15 & 3.3 & $1.6-5.1$ & Fluffy feather \\
\hline Menacanthus stramineus & 15 & 3.3 & $1.8-5.5$ & Base of feather \\
\hline \multicolumn{5}{|l|}{ Tick } \\
\hline Argas persicus & 6 & 1.3 & $0.4-2.4$ & Ventral part of abdomen, leg \\
\hline
\end{tabular}

\section{Age wise prevalence of ectoparasites}

In this study the overall prevalence of ectoparasites was higher in chicks, growers and adults was $17.8 \%, 60.3 \%$ and $80.4 \%$ respectively. The difference was statistically significant $(p<0.05)$. There was no statistical difference $(p>0.05)$ in the prevalence of the different species of ectoparasites between the various age groups with exception $C$. mutans, where the highest prevalence of $C$. mutanswas in the adult $(65.2 \%)$, followed by growers $(44.1 \%)$ and chicks $(0.4 \%)$. The difference was statistically significant $(\mathrm{p}<0.05)$ (Table 3 ). 
Table 3: Prevalence of species of ectoparasites by age groups.

\begin{tabular}{lllll}
\hline Ectoparasite Species & \multicolumn{3}{c}{$\begin{array}{c}\text { Age } \\
\text { (p-value) }\end{array}$} \\
\cline { 2 - 5 } & $\begin{array}{l}\text { Chicks } \\
\text { (n=225) }\end{array}$ & $\begin{array}{l}\text { Grower } \\
(\mathbf{n}=\mathbf{1 7 9})\end{array}$ & $\begin{array}{l}\text { Adult } \\
(\mathbf{n}=\mathbf{4 6})\end{array}$ & \\
\hline Argaspersicus & $3(1.3 \%)$ & $\mathbf{1}(0.6 \%)$ & $2(4.3 \%)$ & $3.994(0.153)$ \\
Cuclotogasterheterographus & $11(4.9 \%)$ & $3(1.7 \%)$ & $2(4.3 \%)$ & $3.095(0.177)$ \\
Menopongallinae & $11(4.9 \%)$ & $4(2.2 \%)$ & $\mathbf{1}(2.2 \%)$ & $2.333(0.342)$ \\
Goniocotesgallinae & $5(2.2 \%)$ & $10(5.6 \%)$ & $0(0.0 \%)$ & $5.290(0.089)$ \\
Menacanthusstramineus & $8(3.6 \%)$ & $\mathbf{6 ( 3 . 4 \% )}$ & $\mathbf{1 ( 2 . 2 \% )}$ & $0.227(0.893)$ \\
Cnemidocoptesmutans & $1(0.4 \%)$ & $\mathbf{7 9}(44.1 \%)$ & $30(65.2 \%)$ & $149.149(0.000)$ \\
Cnemidocoptesgallinae & $1(0.4 \%)$ & $5(2.8 \%)$ & $1(2.2 \%)$ & $3.719(0.106)$ \\
Overall parasite load & $40(17.8)$ & $108(60.3)$ & $37(80.4)$ & $97.869(0.000)$ \\
\hline
\end{tabular}

\section{Sex and breed wise prevalence of ectoparasites}

The overall prevalence of ectoparasites in male and female sex groups was $36.3 \%$ and $44.8 \%$, respectively. The difference in over all prevalence between male and female chickens was statistically significant $(p<0.05)$, nonetheless, the present study revealed no statistical difference $(p>0.05)$ in the prevalence of the various species of ectoparasites between the two sexes except $C$. mutans which was significantly $(p<0.05)$ higher in female than male chickens (Table 4). With regard to breed it was observed that the overall prevalence of ectoparasite was significantly different $(p<0.05)$ between local $(49.2 \%)$ and exotic breeds (19.5\%). In this study, only C. mutans showed statistically significant difference among the breeds where it was higher in local (29.7\%) than exotic breeds (10.6\%) (Table 4 ).

Table 4: Prevalence of species of ectoparasites by sex and breed categories.

\begin{tabular}{|c|c|c|c|c|c|c|}
\hline \multirow[t]{2}{*}{ Ectoparasite Species } & \multicolumn{2}{|c|}{ Sex } & \multirow{2}{*}{$\begin{array}{l}\mathrm{O} 2 \\
\text { (p-value) }\end{array}$} & \multicolumn{2}{|c|}{ Breed } & \multirow{2}{*}{$\begin{array}{l}\mathrm{O} 2 \\
\text { (p-value) }\end{array}$} \\
\hline & $\begin{array}{l}\text { Male } \\
(n=198)\end{array}$ & $\begin{array}{l}\text { Female } \\
(n=252)\end{array}$ & & $\begin{array}{l}\text { Local } \\
(n=327)\end{array}$ & $\begin{array}{l}\text { Rhodes } \\
\text { Island } \\
\text { Red(n=123) }\end{array}$ & \\
\hline Argas persicus & $3(1.55 \%)$ & $3(1.2 \%)$ & $\begin{array}{l}0.088 \\
(0.766)\end{array}$ & $5(1.5 \%)$ & $1(0.8 \%)$ & $\begin{array}{l}0.348 \\
(0.555)\end{array}$ \\
\hline Cuclotogaster heterographus & $5(2.5 \%)$ & $11(4.4 \%)$ & $\begin{array}{l}1.094 \\
(0.320)\end{array}$ & $16(4.9 \%)$ & $0(0 \%)$ & - \\
\hline Menopon gallinae & $9(4.5 \%)$ & $7(2.8 \%)$ & $\begin{array}{l}1.010 \\
(0.443)\end{array}$ & $15(4.6 \%)$ & $1(0.8 \%)$ & $\begin{array}{l}3.713 \\
(0.082)\end{array}$ \\
\hline Goniocotes gallinae & $8(4.0 \%)$ & $7(2.8 \%)$ & $\begin{array}{l}0.549 \\
(0.598)\end{array}$ & $8(2.4 \%)$ & $7(5.7 \%)$ & $\begin{array}{l}2.920 \\
(0.135)\end{array}$ \\
\hline Menacanthus stramineus & $6(3.3 \%)$ & $9(3.6 \%)$ & $\begin{array}{l}0.101 \\
(0.798)\end{array}$ & $15(4.6 \%)$ & $0(0 \%)$ & - \\
\hline Cnemidocoptes mutans & $37(18.7 \%)$ & $73(28.9 \%)$ & $\begin{array}{l}6.346 \\
(0.015)\end{array}$ & $97(29.7 \%)$ & $13(10.6 \%)$ & $\begin{array}{l}17.645 \\
(0.000)\end{array}$ \\
\hline Cnemidocoptes gallinae & $4(2.0)$ & $3(1.2 \%)$ & $\begin{array}{l}0.498 \\
(0.705)\end{array}$ & $5(1.5 \%)$ & $2(1.6 \%)$ & $\begin{array}{l}0.005 \\
(1.000)\end{array}$ \\
\hline Overall prevalence & $72(36.3)$ & $113(44.8)$ & $\begin{array}{l}5.725( \\
0.017)\end{array}$ & $161(49.2)$ & $24(19.5)$ & $\begin{array}{l}33.243 \\
(0.000)\end{array}$ \\
\hline
\end{tabular}




\section{Discussion}

The overall prevalence of ectoparasites in the study area was $40 \%$. The result is comparable to the study conducted in South-eastern Nigeria village chickens, where $41.1 \%$ chickens were infested by various species of ectoparasites (Nandi and George, 2009). Prevalence ranging from 78.0\%-97.3\% have been reported in various part of the country (Bersabeh Tigabu, 1999; Hagos Ashenafi, 2000). This discrepancy might have occurred due to agro-ecology, management, climatic factors in the study area and sample size and differences in sampling time.

Mites were more prevalent comprising $26 \%$ of the total infestations followed by lice $(13.8 \%)$ and ticks (1.3\%) (p<0.05). Yeshitila Amede et al. (2011) reported mites as the most prevalent ectoparasite in village chickens. Other studies reported lower prevalence of mites, ranging from 8.1\%- 19.5\% (Hagos Ashenafi and Eshetu Yimer, 2005; Solomon Mekuria and Elsabet Gezahegn, 2010). The higher prevalence of mites in the current study areas might be associated with poor hygiene of chicken houses as well as lack of control measures towards such parasites. Of the ectoparasites, lice infestation was registered as the second most in village chickens in contrary to Solomon and Elsabet Gezahegn (2010) who reported lice as the first most prevalent (88\%). In the present study there were no fleas registered as was the report made by Adene and Dipeolu (1975) in West Nigeria. However, flea has been recorded with various rate of prevalence in the country and elsewhere in the world (Kelay Belihu et al., 2009; Sabuni, 2009; Yeshitila Amede, 2011). In general, the variation in the occurrence of ectoparasites in the different areas might be due to differences in the management system.

The species of ectoparasites registered in present study includes, C. mutans, which had the highest prevalence $61.1 \%$ followed by $C$. heterographus, $M$. gallinae, G. gallinae, M. stramineus, C. gallinaeand, A. persicus with a respective prevalence of $8.9 \%, 8.9 \%, 8.3 \%, 8.3 \%, 3.9 \%$ and $3.3 \%$, respectively. These ectoparasites have commonly been identified in free range chickens (Permin et al., 2002; Ekpo et al. 2010). The observed level and diversity of ectoparasites in the present study could strongly be related with the poor hygiene and management practices which could favor propagation and fasten the life cycle of the parasites. 
In the present study a significantly $(p<0.05)$ higher overall prevalence of ectoparasite was found in adult (65.2\%) and growers (44.1\%) than in chicks $(0.4 \%)$. These might be due to the reason that older chickens maybe are exposed longer to the infested environment than the chicks, hence a higher prevalence rates. In addition adult chickens scavenge through a wider area of the farmers' homesteads and beyond that makes them more exposed to the source of infestation.

The overall prevalence of ectoparasites was found to be significantly $(\mathrm{p}<0.05)$ higher in female $(44.8 \%)$ than in male (36.3\%). Similarly Biu et al. (2007) found that female chickens had a higher prevalence of ectoparasites than male chickens in Nigeria. The higher prevalence could be related to the broody nature of hens where compared to male they tend to spend most of their time incubating and less time is devoted to grooming, preening, parching and rocking. In contrast Mungube et al. (2008) from Kenya, reported that males had a slightly higher rate of occurrence of ectoparasites compared to females. Additionally, Sabuni et al. (2010) and Bala et al. (2011) stated that there is no direct relationship between sex and the occurrence of ectoparasites. This discrepancy might be due to the difference in locality or sampling procedures or other factors.

In the current study a significant number of local (49.2\%) chickens were found to be infested compared to exotic (19.5\%) breeds. Similarly, Firaol Tamiru et al. (2014) in their study in an intensive farm found out that local breed chickens $(87.55 \%)$ were more infested than exotic breed chickens $(26.4 \%)$ with statistical significance difference; however, in the present study both local and exotic breeds were managed in a similar condition and hence the higher prevalence in local breeds might have risen due to the large number of local chickens sampled or other factor.

Only two species of mites namely, C. mutans and C. gallinae were observed where C. mutans (24.4\%) was the predominant one as was reported by Hagos Ashenafi and Eshetu Yimer (2005) from Central Ethiopia. C. mutans is one of the dozen related species of scaly leg mites occurring on various chickens (Taylor et al., 2007; Swai et al., 2010). With regard to sex, age and breed, C. mutans was significantly $(\mathrm{p}<0.05)$ higher in female than male; in adult chickens than in grower and chicks; in local than exotic chickens. The likely explanation is unclear and it needs further research. Adult chickens may 
have had higher prevalence due to their gregariousness relative to growers and chicks. Similar observation was made by Solomon and Elsabet Gezahegn (2010). The dominances of mites in the local than in the exotic breed could due to the large number of local chickens sampled or other factor; otherwise there is no plausible explanation for it hence it needs to be further researched.

Out of the four lice species, $C$. heterographus and $M$. gallinae, were the dominant ones and they were also reported previously (Kelay Belihu et al., 2009). However, Yeshitila Amede et al.(2011) reported C. heterographus to be the least prevalent as compared to other species of lice. In agreement with our finding, Kelay Belihu et al. (2009) reported $M$. gallinae as the second most lice species. There was no significant statistical variation $(p>0.05)$ in the prevalence of lice among sex and age groups as was observed in previous studies elsewhere (Yeshitila Amede et al., 2011; Bala et al., 2011). Although it has been stated that sex is not an influential factor on the prevalence rates of ectoparasites in poultry, it was speculated that some host factors may occasionally cause variation in louse prevalence in some cases (Ekpo et al., 2010). However, further research is required to come up with plausible explanation to harmonize these conflicting reports.

In this study $A$. persicuswas the only tick species identified and it was also the least prevalent (1.3\%) ectoparasite recorded, which was lower than the report of Kelay Belihu et al. (2010) (5.3\%) in East Shoa. The lower prevalence in the current study might be due to the feeding habit of the parasite where it briefly visits the host usually at night; hence it may not be found abundantly at sampling during the day time. However, the low prevalence of $A$. persicus should not be undermined because of its effect on human health especially in rural areas where there is close association between man and domestic fowls (Sadiq et al., 2003). There was no statistical significant difference $(\mathrm{p}>0.05)$ in the prevalence of ticks (A. persicus) among the different sex, breeds and age categories. Ticks were described to have no significant association with age and sex (Solomon Mekuria and Elsabet Gezahegn, 2010).

\section{Conclusion}

The chickens in backyard production system in the study area were found to harbor diverse external parasite infestation. Owing to the inherent nature of the management of chicken in rural areas, infectious and parasitic diseases are wide spread exerting their confounding effects on productivity. 
Therefore, increasing awareness of the farmers through extension work and application of suitable pesticides routinely in the backyard production system is recommended. Further research should be conducted to confirm the impact of these parasites on health and productive performance of backyard chickens, including cost effectiveness of control strategies.

\section{Acknowledgements}

The authors would like to thank the Wolita Sodo Zone Parasitology Laboratory staff members for the help rendered during the study period.

\section{References}

Adene, D.F. and Dipeolu, O.O.,1975. Survey of blood and ectoparasites of domestic fowls in Ibadan, Western State of Nigeria. Bull. Anim. Hlth. Prod. Afr., 23, 333-335.

Aleya, B. and Sabrina, S., 2011. Prevalence and seasonal variation of ectoparasite in pigeon, Columba livia (gmelin, 1789) of Dhaka, Bangladesh. Bangladesh $J$. Zoology, 39, 223-230.

Ashenafi, H. and Yimer, E., 2004. Study on Gastrointestinal Helminths of Local Chickens in Central Ethiopia. J. Vet. Med.,155, 504-507.

Ashanafi, H., 2000. Survey on identification of major diseases of local chickens in three selected agro-climatic zones of Central Ethiopia. DVM thesis, Addis Ababa University, Ethiopia.

Ashenafi, H. and Yimer, E., 2005. Ectoparasites of local scavenging chickens of Central Ethiopia. Eth. J. Sci., 28, 69-74.

Bagust, T.J., 1999. Improvement health for poultry production in Asia, a development of perspective. Avian Pathol., 23, 395-404.

Bala, Y., Anka, S.A., Waziri, A. and Shehu, H., 2011. Preliminary Survey of Ectoparasites Infesting Chickens (Gallus domesticus) in Four Areas of Sokoto Metropolis. Nigerian J. Basic Applied Sci., 19,173-180.

Belihu, K., Mamo, A., Lobago, F. and Ayana, D., 2009. Prevalence of ectoparasites in backyard local chickens in three agro-ecological zones of East Shoa, Ethiopia. Rev. Méd. Vét.,11, 537-541.

Biu, A.A., Agbede, R.I. and Peace, P., 2007. Studies on ectoparasites of poultry in Maiduguri, Nigeria. NigerianJ. Parasitol., 28, 69-72.

CSA, 2009. Agricultural survey. Report on livestock, poultry and bee hives population, private peasant holdings. Addis Ababa, Ethiopia. 
Dessie, T. and Ogle, B., 2001. Village poultry production systems in the central highlands of Ethiopia. Trop. Anim. Hlth Prod., 33(6): 521-537.

Ekpo, U. F. Ogbooye, A.A. Oluwole, A.S. and Takeet, M., 2010. A preliminary survey on the parasites of free range chicken in Abeokuta, Ogun state, Nigeria. J. Natural Sci. Eng. Tech., 9, 123-130.

Tamiru, F., Dagmawit, A., Askale, G., Solomon, S., Morka, D, Waktole, T., 2014. Prevalence of Ectoparasite Infestation in Chicken in and Around Ambo Town, Ethiopia. J. Veterinar Sci. Technol., 5, 189.

Hunduma, D., Regassa, C., Fufa, D., Endale, B. and Samson, L., 2010. Major Constraints and Health Management of Village Poultry Production in Rift Valley of Oromia, Ethiopia. American-Eurasian J. Agr. Envt. Sci., 9,529-533.

Magwisha, H.B., Kassuku, A.A., Kvysgaard, N.C. and Permin, A., 2002. A comparison of the prevalence and burdens of helminth infections in growers and adult freerange chickens. Trop. Anm. Hth. Prod., 34, 205-214.

Mekonnen, G., 2007. Characterization of the Small Holder Poultry Production and Marketing System of Dale, Wonsho and Loka Abaya Weredas of SNNPRS. MSc thesis, Hawassa University College of Agriculture, Ethiopia.

Mekuria, S. and Elsabet, G., 2010. Prevalence of external parasites of poultry in intensive and backyard chicken farm at WolaitaSodo town, southern Ethiopia. Vet. World, 3,533-535.

Mungube, E.O., Baun, S.M., Tenhagen, B.A., Wamae, L.W., Nzioka, S.M., Muhammed, L. and Nginyi, J.M., 2008. "Prevalence of Parasites of the Local Scavenging Chickens in a Selected Semi-Arid Zone of Eastern Kenya", Tropical Trop. Anm. Hlth. Prod., 40, 101-109.

Nanadi, P.A. and George, S.O., 2009. A cross-sectional survey on parasites of chickens of selected villages in the sub humid zones of South-eastern Nigeria. J. Parasitol. Res.,doi:10.1155/2010/141824.

Permin, A., Esmann, J. B., Hoj, C. H., Hove, T. and Mukatirwa, S., 2002. Ecto-, Endoand Haemoparasites in free range chicken in the Gomoronzi District in Zimbabwe. Prev. Vet. Med., 54, 213-224.

Pfeiffer, D.V., 2002. An introduction to veterinary epidemiology. The Royal Veterinary College. University of London UK.

Reta, D., 2009. Understanding the role of indigenous chickens during the long walk to food security in Ethiopia. Livestock Res. Rural Devt.,21. 
Sabuni, A. Z., 2009. Prevalence, intensity and pathology of ecto andHaemoparasites infections in indigenous chickens in eastern Province of Kenya. MSc thesis, University of Nairobi, Kenya.

Sabuni, A.Z., Mbuthia, P.G., Maingi, N., Nyaga, P.N., Njagi, L.W., Behora, L.C. and Michieka, J.N., 2010. Prevalence of ectoparasites infestation in indigenous free ranging village chickens in different agro-ecological zones of Kenya. Livestock Res. Rural Devt., 22.

Sadiq, N.A., Adejinmi, J.O, Adedokun, O.A., Fashanu, S.O., Alimi, A. A. and Sofunmade, Y.T., 2003. Ectoparasites and haemoparasites of indigenous chicken (Gallus domesticus) in Ibadan and environs. Trop. Vet.,21: 187-191.

Soulsby, E.J.L., 1982. Helminths, Arthropods and Protozoa of Domestic animals, 7th edn., Bailliere and Tindall, East Sussex, London, UK.

Swai, E. S., Kessy, M., Sanka, P., Bwanga, S. and Kaaya, J. E., 2010. A survey on ectoparasites and heamoparasites of free-range indigenous chickens of Northern Tanzania. Livestock Res. Rural Devt., 22(9).

SZWRDO , 2012. Sodo ZuriaWoreda Rural Development Office, Wolayita Sodo, Ethiopia.

Taylor, M.A., Coop, R.L. and Andwall, R.L., 2007. Veterinary Parasitology, 3rd ed., Blackwell Science, Ltd., London, UK.

Thrusfield, M., 2005. Veterinary epidemiology, 3rd ed., Black well science Ltd. London.

Tigabu, B., 1999. Survey of ectoparasites and gastrointestinal helminthes of backyard Chickens in three selected agro-climatic zones in Central Ethiopia. DVM thesis, Addis Ababa University, Ethiopia.

Vegad, J.L., 2004. Poultry Diseases: A guide for Farmers and Poultry Professionals, 1st ed., International Book Distributing Company, India.

Weswne, A., Asfaw, T., Genete, B., Kassa, B. and Dorchies, P.H., 1997. Comparative Studies of external parasites and gastrointestinal helminthes of chickens kept under different management system in and around Addis Ababa, Ethiopia. Rev. Méd. Vét., 148, 497-500.

Yeshitela, A., Kefelegn, T., and Mihreteab, B., 2011. Prevalence of Ectoparasites in Haramaya University Intensive Poultry Farm. Global Vet., 7, 264-269.

Zeryehun, T., Eshetu, A. and Zeru, H., 2012. Helminthosis of Chickens in Selected Small Scale Commercial Poultry Farms in and around Haramaya Woreda, Southeastern Ethiopia. J. Vet. Adv.,2, 462-468. 